\title{
Québec forest ecological classification program
}

\author{
by Jean-François Bergeron ${ }^{1}$, Jean-Pierre Saucier ${ }^{2}$, André Robitaille ${ }^{3}$ and Denis Robert ${ }^{2}$
}

\begin{abstract}
In 1986, the ministère des Forêts du Québec instituted a provincial program to study forest ecosystems entitled the "Forest Ecological Classification (FEC) Program."' Under this program, a multidisciplinary team was charged with conducting ecological surveys, analyzing and characterizing the variables of the physical environment, classifying vegetation and preparing integrated forest inventory maps. Their goal is to complete the ecological classification of the forests in all territories south of the 52 nd parallel. To undertake such a vast project, it was necessary to prepare detailed methodological guides for data collection, data analysis and mapping. The following products are now available for many different ecological regions: classifications of forest types, toposequences, physiographic and surface deposit maps and integrated forest inventory maps. Multivariate analysis methods are used in analyzing ecological data; in this way, hierarchical classifications and ordinations can be used as the basis for identifying and describing forest types, vegetation-physical environment relationships and successional patterns. Such ecological classification products are an indispensable tool for forest managers and users.
\end{abstract}

Key words: ecological classification, forest ecology, forest management, forest site classification, multivariate analysis, physical environment, Québec.

\section{Résumé}

Dès 1986, le ministère des Forêts du Québec a mis sur pied un programme provincial de connaissance des écosystèmes forestiers nommé "cadre écologique forestier (CEF)». Une équipe multidisciplinaire est responsable de la réalisation de travaux d'inventaire écologique, de classification de la végétation, d'analyse et de caractérisation des variables du milieu physique, et de cartographie écoforestière intégrée. Ce programme vise à compléter la classification écologique du territoire pour l'ensemble des forêts au sud du $52^{\mathrm{C}}$ parallèle. L'ampleur d'un tel mandat a nécessité l'élaboration de guides méthodologiques détaillés de prise de données, d'analyse des données et de cartographie. Les produits suivants sont désormais disponibles pour nombre de régions écologiques : classifications des types forestiers, chênes de sols, cartes du relief et des dépôts de surface et cartes d'inventaires forestiers intégrées. Les méthodes d'analyse multifactorielle sont utilisées dans l'analyse des données écologiques. Ainsi, la classification des types forestiers, les relations végétation-milieu physique et les formes de succession sont élaborées à partir des ordinations et des classifications hiérarchiques. Ces produits de classification écologique constituent un outil indispensable pour l'aménagement et l'utilisation du milieu forestier.

Mots clés : aménagement forestier, analyse multifactorielle, classification écologique, classification des sites forestiers, écologie forestière, milieu physique, Québec.

\section{Introduction}

After the adoption of the Forest Act in 1986, the gouvernement du Quéebec implemented a new forest policy based on the principles of protection, multipurpose use and sustained yield. Guided by these principles, the ministère des Forêts du Québec (MFO) is striving to improve forest management practices and optimize forest production for timber, wildlife and recreation opportunities. To achieve these goals, it was necessary to initiate a provincial program to study forest resources under the auspices of the Service des inventaires forestiers (SIF). This program focuses on the study and classification of forest ecosystems and the evaluation of their dendrometric characteristics. This paper will summarize the ecological classification activities that fall within the scope of the "Québec Forest Ecological Classification (FEC) Program" and the principles on which they are based.

Since 1986, a multidisciplinary SIF team made up of foresters, biologists, geomorphologists and a pedologist has been responsible for conducting standardized ecological forest surveys, characterizing the principal ecological variables (physiography and surface deposits), determining the relationships between vegetation and the physical environment and classifying the forest vegetation. The principal intended use for the FEC Program is to provide information and tools to field-level managers which will guide them in selecting and applying forest management systems and silvicultural

\footnotetext{
${ }^{1}$ Biologist, ${ }^{2}$ foresters, ${ }^{3}$ geomorphologist, Service des inventaires forestiers, Ministère des Forêts du Québec, $5700,4^{\mathrm{e}}$ avenue ouest, bureau E-301, Charlesbourg (Québec), Canada G1H 6R1.
}

techniques. In Québec, forest management decisions are to be guided by a knowledge of the composition, structure and functions of forest ecosystems to ensure sustained yield and multipurpose forest use. Thus it has become a matter of vital importance to understand the forest's regenerative capacity and the successional behaviour and pattern of ecosystems after disturbances due to both natural (i.e. fire, insect infestation) and human causes (i.e. harvesting). Knowledge of forest ecosystems is also necessary for selecting the species best adapted to the environment and those which can achieve higher yields.

The classification results are expressed under the Québec hierarchical system of ecological land classification (Jurdant et al. 1977). This ecosystematic classification system, which integrates all the physical and biological components of a land area, has been widely applied in the Canadian provinces (Thie and Ironside 1977), the United States (Bailey 1976; Wertz and Arnold 1972) and Australia (Christian and Stewart 1968). In Québec, the concepts of ecological region, ecological district, ecological type and phase (previously developed by Jurdant et al. 1977) are widely applied in ecological land surveys involving universities (e.g. Bélanger et al. 1983, Bergeron et al. 1983, Bouchard et al. 1985), the MFO and the ministère de l'Environnement du Québec (MENVIQ) (Bélanger et al. 1992). The MENVIQ ecological framework (Ducruc 1986, Gérardin and Ducruc 1990) serves as a basis for the preparation of land development plans of the "municipalités régionales de comté." The hierarchical structure of ecological land classification applied in the MFO's FEC program is presented in Figure 1. 
Level 1: Ecologicol region

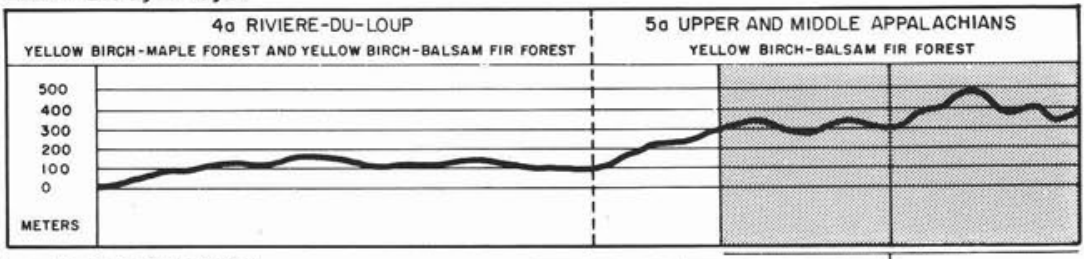

Level 2: Ecological district

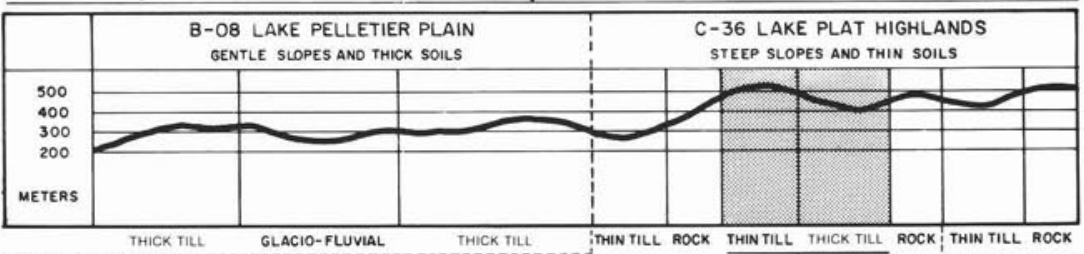

1. THICK TLL E ITHN TILL ROCK THIN TILL THICK TILL ROCK THIN TILL ROCK

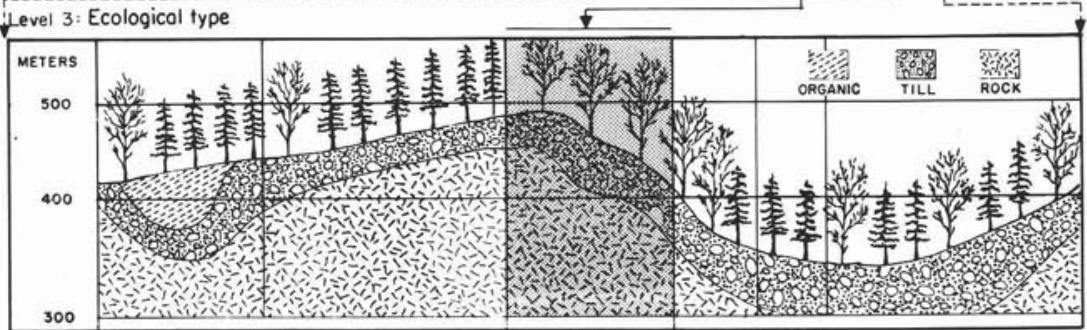

300

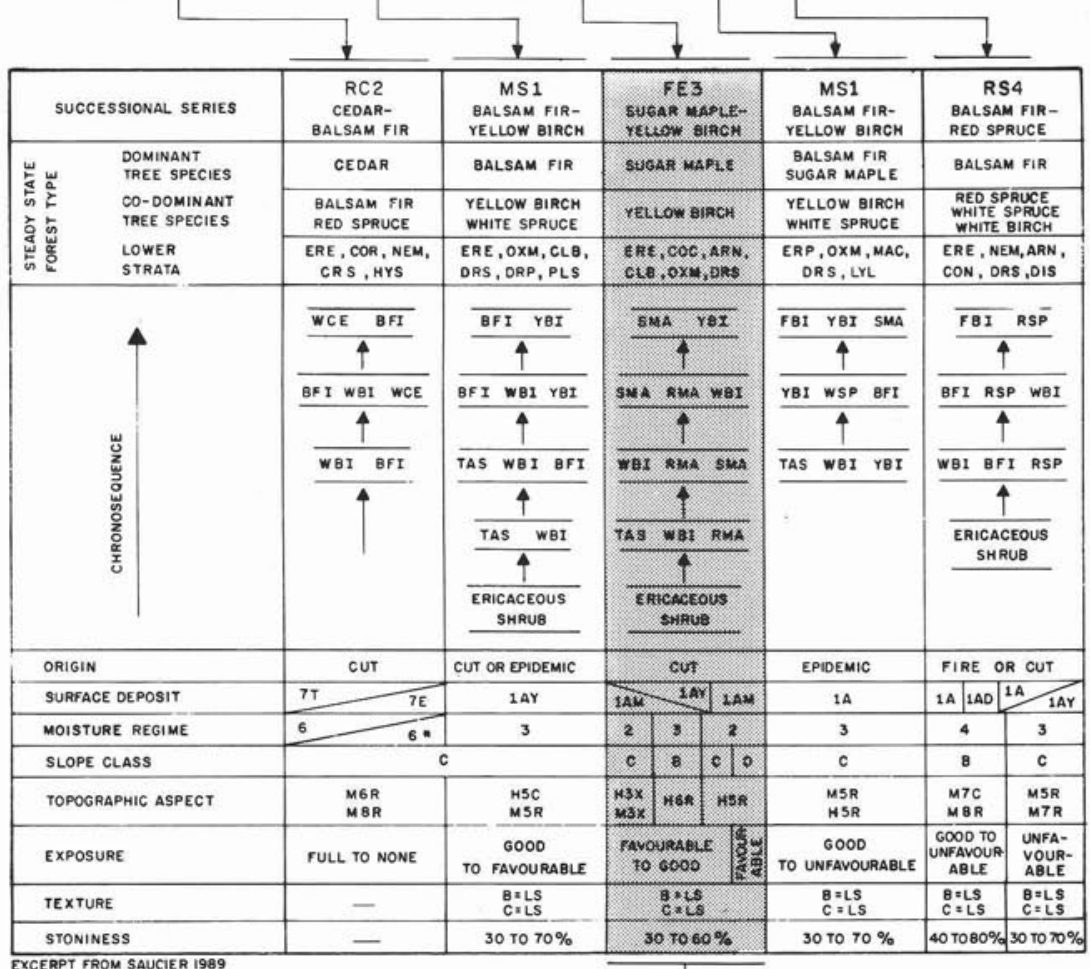

Level 4 : Ecological phose

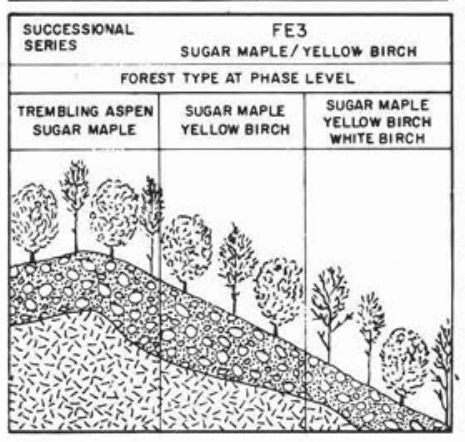

\begin{tabular}{|c|c|c|c|}
\hline \multicolumn{4}{|c|}{ FOREST TYPE ( PHASE LEVEL) } \\
\hline$=$ & $\begin{array}{l}\text { TREMBLING ASPEN } \\
\text { SUGAR MAPLE }\end{array}$ & $\begin{array}{l}\text { SUGAR MAPLE } \\
\text { YELLOW BIRCH }\end{array}$ & $\begin{array}{l}\text { SUGAR MAPLE } \\
\text { YELOW BIRCH } \\
\text { WHIITE BIRCH }\end{array}$ \\
\hline $\begin{array}{l}\text { DOMINANT/ } \\
\text { CO-DOMINANT } \\
\text { TREE SPECIES }\end{array}$ & $\begin{array}{l}\text { TREMBUING ASPEN/ } \\
\text { SUGAR MAPLE } \\
\text { RED MAPLE } \\
\text { WHITE BIRCH } \\
\text { YELLOW BIRCH }\end{array}$ & $\begin{array}{l}\text { SUGAR MAPLE / } \\
\text { YELOW BIRCH }\end{array}$ & $\begin{array}{l}\text { SUGAR MAPLE } \\
\text { YULLWW BIRCH, } \\
\text { WHITE BIRCH } \\
\text { BALSAM FIR } \\
\text { WHITE SPRUCE }\end{array}$ \\
\hline $\begin{array}{l}\text { LOWER } \\
\text { STRATA }\end{array}$ & $\begin{array}{l}\text { ERE COC } \\
\text { ERP ASM ORS }\end{array}$ & $\begin{array}{ll}\text { COC } & \text { ERE } \\
\text { CLB } & \text { ORN } \\
\end{array}$ & $\begin{array}{ll}\text { ERP } & \text { ERE VIL } \\
\text { RUI } & \text { ORP } \text { ORS }\end{array}$ \\
\hline $\begin{array}{l}\text { SPECIES } \\
\text { GROUP }\end{array}$ & PE & ERBJ & EREB \\
\hline $\begin{array}{l}\text { DENSITY/ } \\
\text { HEIGHT }\end{array}$ & 82 & A2 & $A^{2}$ \\
\hline $\begin{array}{l}\text { AGE } \\
\text { CLASS }\end{array}$ & 50 & OLD UNEVEN & 70 \\
\hline DISTURBANCE & FIRE CUT & - & FIRE CUT \\
\hline
\end{tabular}

Figure 1. Québec's hierarchical structure of ecological land classification. Four classification levels have been defined. An equivalent number of mapping scales correspond to these levels: region, district, type and phase. A synthetic example of toposequence is shown at level 3. Level 4 describes the species composition and stand characteristics of forest types at the phase level. These results are part of the forest ecological classification of 5a-Basses et Moyennes Appalaches ecological region (Saucier 1989). Acronyms and codes used in this figure are described in Robert and Saucier (1988). 
The analytical concepts, methods and algorithms used in the classification work are based on the analytical procedures most commonly used in forest ecology in Canada (especially Ontario: Jones et al. 1983, Sims et al. 1989). Vegetation and vegetation-physical environment relationships are analyzed through the use of multivariate numerical methods (Hill 1979a, ter Braak 1987). All stages of the FEC program are computerized. Field microcomputers are used for on-site data collection and microcomputers are used for on-site data collection and microcomputers are used for data processing and analysis.

\section{Ecological District}

To understand the nature and distribution of vegetation within ecological regions (i.e. a segment of land characterized by a distinctive regional climate as expressed by the vegetation; Jurdant et al. 1977), a survey of the biotic and abiotic features is required. To map certain crucial abiotic features which constitute the physiographic components of southern Québec we selected the second level of Jurdant's ecological land classification (Jurdant et al. 1977): the ecological district. An ecological district is defined as a "portion of land characterized by a distinctive pattern of relief, geology, geomorphology and regional vegetation" expressed at a scale of $1: 250,000$. Defined this way, it corresponds to the "land district" of Lacate (1969) and resembles the "site district" of Hills (1959). At this level, the factors that delimit mapping units are the characteristics of the physical environment. Vegetation cannot serve as a discriminant feature for delimiting mapping units: this conclusion is shared by Damman (1979) and Jurdant et al. (1969). Ecological systems and subsystems also assist in the mapping of the regional topography and geomorphology (Bélanger et al. 1991).
After several years of experimentation in various regions of Québec, we have developed a cartographic method specifically designed for describing and mapping ecological districts (Robitaille 1988) that includes a relief classification adapted to Québec's land area (Robitaille and Saucier 1989). To date, nearly $360,000 \mathrm{~km}^{2}$ of a total $652,000 \mathrm{~km}^{2}$ in southern Québec have been mapped. Several different ecological regions have been defined in the process (Figure 2). Ecological district maps at a scale of 1:250,000, surface deposit maps at 1:50,000, district data bases, physical environment characterization summaries and field guides for the identification of surface deposits have been produced.

\section{Ecological Survey}

Within each ecological region, ecological surveys are conducted to define the composition, structure, and spatial dynamics of the forested ecosystems. To standardize the data collection procedure, a rigorous methodology was developed. It ensures objective, non-biased data representative of the environment's variability throughout the ecological region. Since 1986, sample collection at more than 14,000 sampling plots (the basic unit) has been carried out (Figure 3). Sampling standards are established in a document entitled "Normes de prises de données et de vérification"' (Robert and Saucier 1988). The ecological survey covers 270000 $\mathrm{km}^{2}$ in hardwood, mixed and boreal forest zones (after Thibault 1985).

\section{Methodology}

Working from a preliminary photo-interpretation of the vegetation, the data collector plots a transect line across a representative topographical segment of a district. Six temporary sampling plots $\left(400 \mathrm{~m}^{2}\right)$ are positioned along the

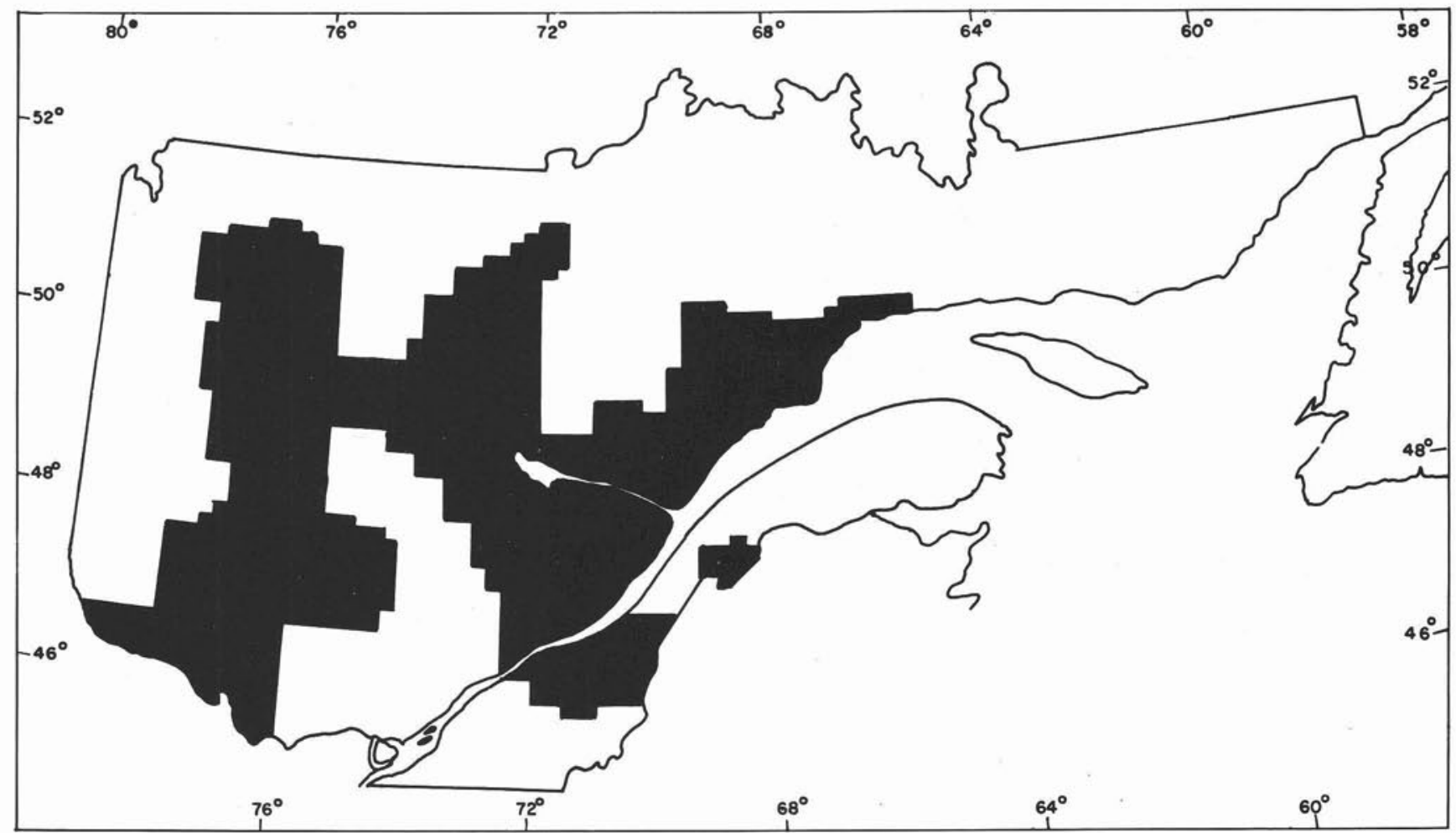

Figure 2. Mapping of ecological districts $(1: 250,000)$ and surface deposits $(1: 50,000)$ in southern Québec. The dark areas have both ecological district and surface deposit maps. 


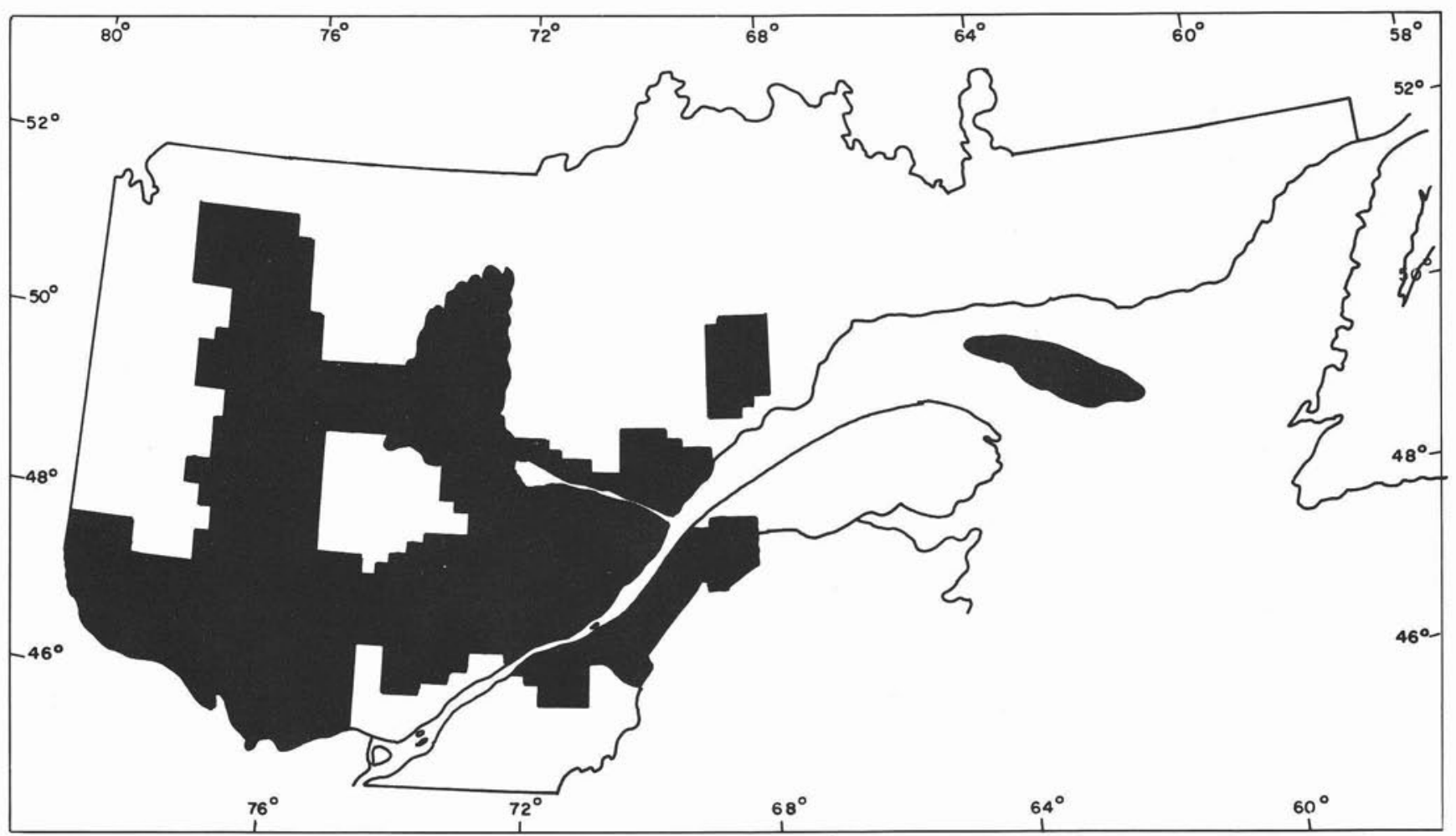

Figure 3. Area covered by the forest ecological inventory. There are more than 14,000 sampling plots in the dark areas.

transect line, which is less than $1.5 \mathrm{~km}$ in length. The sampling intensity is one plot per $15 \mathrm{~km}^{2}$ for the hardwood forest zone, one plot per $20 \mathrm{~km}^{2}$ for the mixed forest zone and one plot per $25 \mathrm{~km}^{2}$ for the boreal forest zone. Each plot is described in terms of its topographical, geomorphological and soil characteristics (52 abiotic variables in total), vegetation structure and species composition. On-site data collection is carried out by SIF forest technicians and by consulting firms contracted by SIF. To ensure the highest degree of precision, collected data are audited by a team of SIF forest technicians and foresters. Then vegetation and physical environment data are stored in data files on a microcomputer (Figure 4).

\section{Forest Ecosystem Classification}

Activities pertaining to classification of forest types have a number of specific objectives. These are outlined below.

- Development of forest type classification. A forest type (vegetation type) is characterized by the homogeneity of its overstory and understory species and by the homogeneity of its structure and physiognomy. A forest type occupies sites whose abiotic characteristics are confined to known limits. It possesses its own successional dynamics and a particular distribution.

- Definition of the relationships between the significant abiotic variables and forest vegetation, as well as production of autecological analyses.

- Characterization of the physical environment associated with each forest type, especially for variables important to forest managers: moisture regime, surface deposit, slope, topography, exposure, texture, stoniness and terrain roughness.
- Development of chronosequences and successional series for related forest types.

- Development and production of management interpretations required by forest managers and users (e.g. field guides to the identification of forest types).

The use of multivariate numerical analysis methods is preferred because it eliminates the subjectivity inherent in non-numerical methods. The methods selected also make it possible to process a great number of sampling plots (800-1000) within a short time. The stages of classification analysis are illustrated in Figure 4. The DCA (derived from the DECORANA program, Hill 1979a) and DCCA (derived from the CANOCO program, ter Braak 1987) ordinations organize the sampling plot and species data statistically to explain species variability within forest types. These ordinations are also used to detect the principal abiotic gradients as expressed by the observed variability in vegetation. The TWINSPAN hierarchical classification method (Hill 1979b) is then used to group sampling plots that share similar species composition. The forest types so defined are presented within a hierarchical structure in which each forest type has a distinct overstory and understory species composition, in addition to being defined by a set of indicator species. The classification results are expressed by forest type identification keys or classification dendrograms (Figure 5).

By comparing ordination and classification results, we have been able to refine the definition of forest types, since the abiotic conditions of each type are known. At this stage, forest types derived from the TWINSPAN classification may be further subdivided on the basis of abiotic conditions. When TWINSPAN divisions are too numerous or do not have ecological significance, the resulting groups can be amalgamated. Site conditions associated with each forest type can 


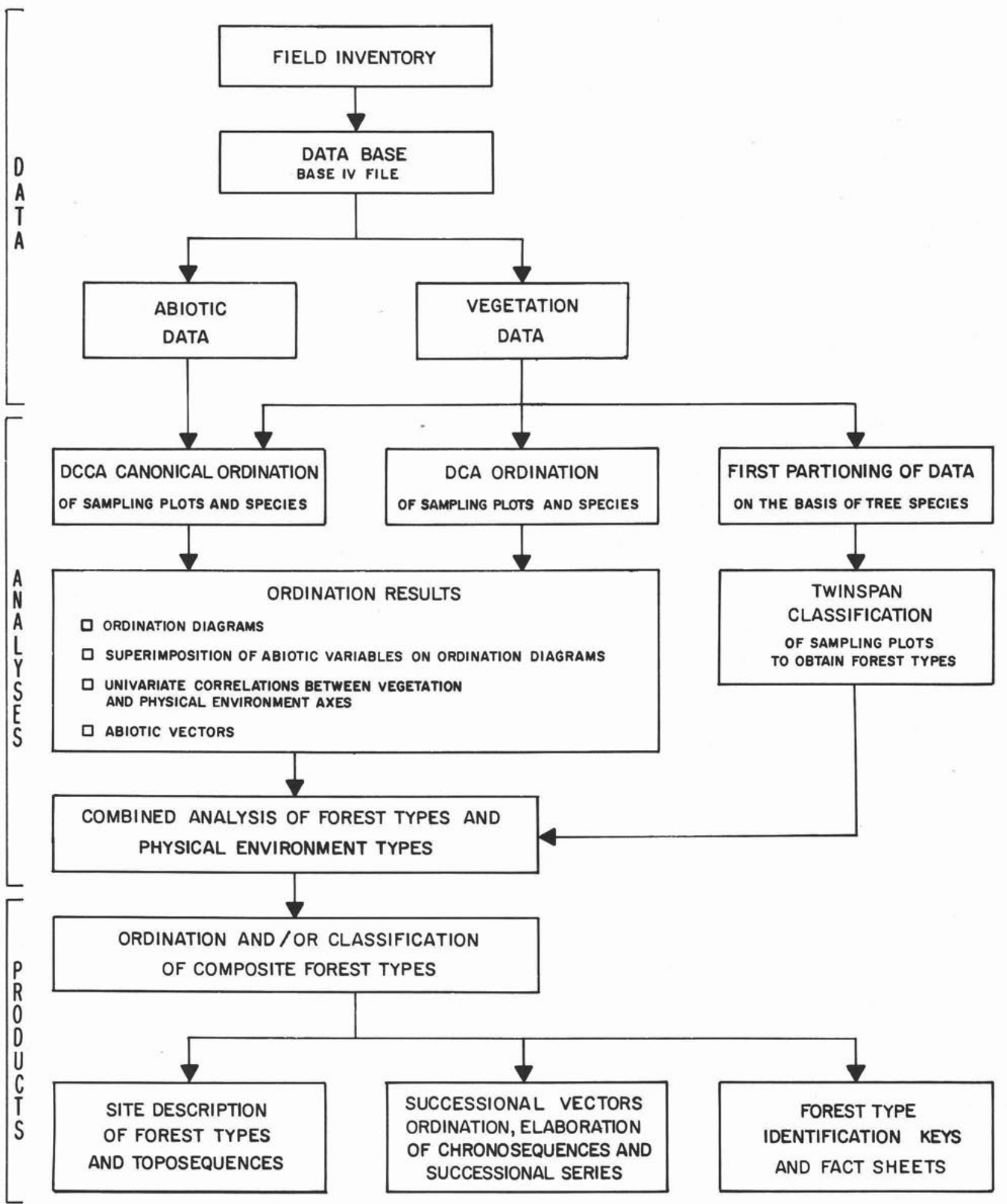

Figure 4. Vegetation and physical environment data analysis in relation to development of forest types, successional series and vegetation-physical environment relationships. (DCA/DCCA $=$ detrended correspondence analysis; detrended canonical correspondence analysis.)

be represented by various simple techniques. In addition to histograms illustrating the distribution of abiotic parameters for each forest type, toposequences (Figure 1, level 3) were also developed. Toposequences ("sères physiographiques") illustrate the distribution of potential steady-state forest types along a topographic gradient. These steady-state forest types are identified as potential climax associations in Daubenmire's forest habitat-type classification (Daubenmire 1952). Within this graphic representation, variables such as altitude, surface deposit, stoniness, texture and moisture regime are also represented.

Let us define chronosequence and successional series next. A chronosequence, as a part of a successional series, is the entire progression of seral stages or phases from a pioneer 


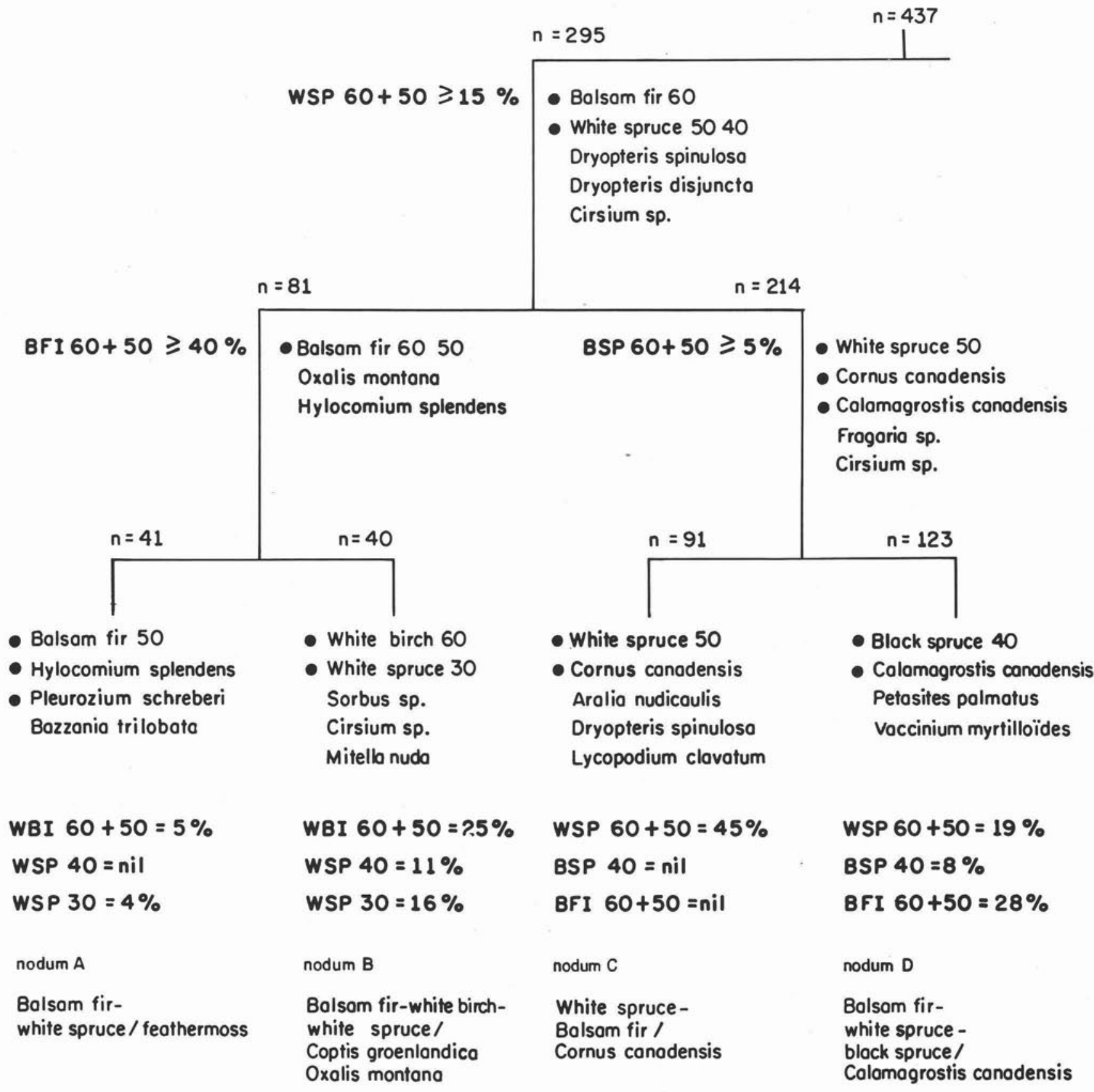

Figure 5. TWINSPAN classification dendrogram of 437 sampling plots from Anticosti Island (only the left part is shown). The number (i.e. 60 , 50 , 40,30 ) accompanying each tree species indicates a tree height class. 60 corresponds to the $\geq 12 \mathrm{~m}$ height class; 30 corresponds to the $\leq 1 \mathrm{~m}$ height class (regeneration). Among the preferential species, the ones with a dot $(\cdot)$ correspond to indicators. Tree species acronyms in bold character correspond to dominant species that help the identification of a forest type or nodum on the dendrogram. BFI, BSP, WSP, WBI stand for balsam fir, black spruce, white spruce and white birch respectively. These results are part of the forest ecological classification of the 10a-Anticosti ecological region (Bergeron 1992a).

vegetation type to a steady-state vegetation type. A chronosequence may also follow a retrogressive and a cyclic pattern. A successional series ("série évolutive") pools together chronosequences (and their respective vegetation types) that lead to the same steady-state forest community (or forest type), as defined in terms of tree species composition and physiognomy. According to Rey (1960) and Ozenda (1964), a successional series (or "série de végétation") groups vegetation types linked in the same chronosequence either progressively or retrogressively.

Daubenmire (1952) defines a series as a group of habitattypes with the same dominant climax species, a habitat-type being a part of the landscape supporting particular climax associations. The use of the term "successional series" in this paper follows these concepts.

Chronosequences forming a successional series can be found in association with various site conditions and may be related to different disturbances. The chronosequences of the same series share the same range of moisture regime conditions, i.e. xeric, mesic or hydric. A DCA ordination applied solely to tree species (after Goff and Zedler 1972) enables us to establish successional vectors (Figure 6) which are translated into chronosequences (Figure 1, level 3). An understanding of the abiotic conditions associated with chronosequences helps us define the series subsequently. 


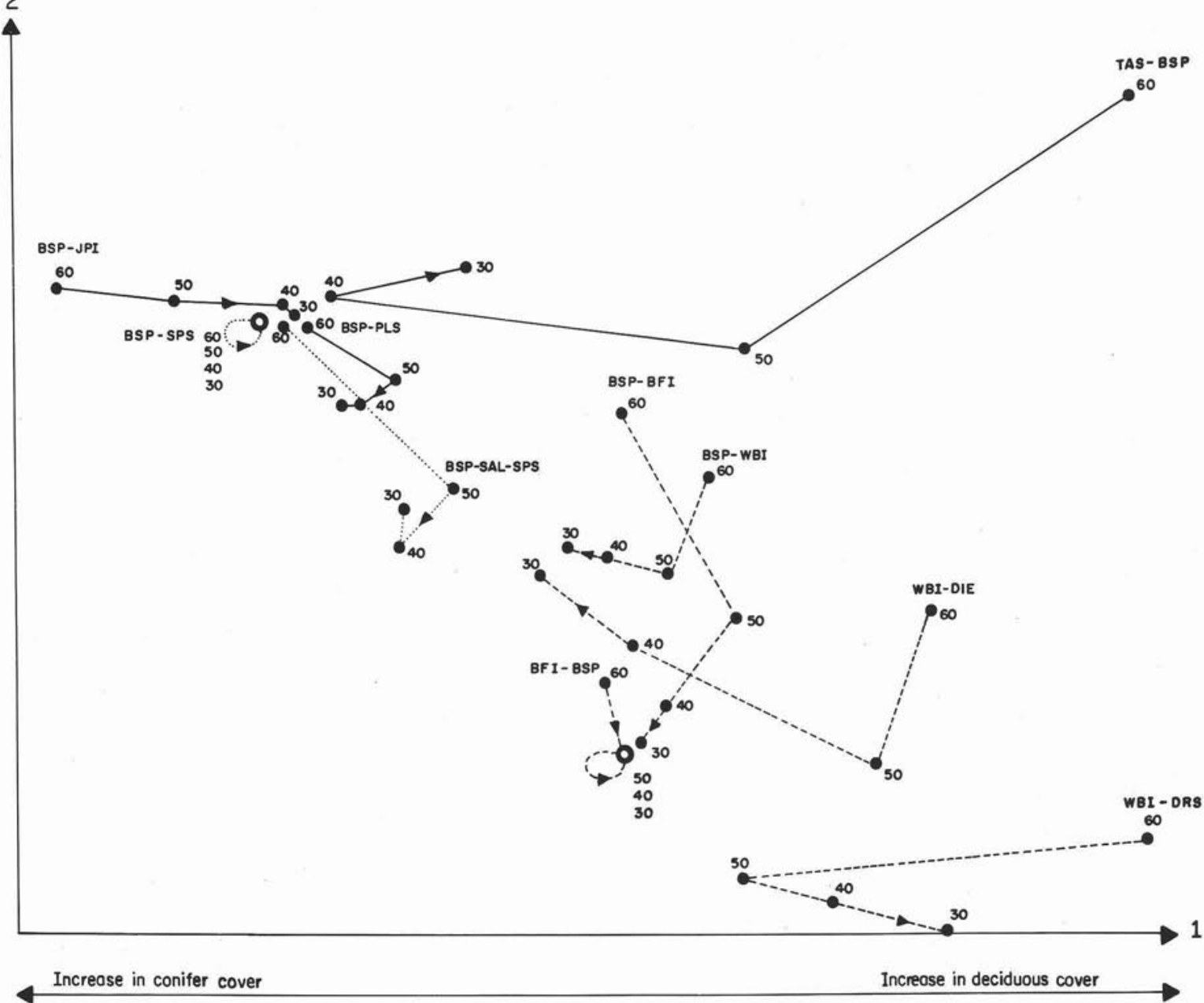

Figure 6. Successional vector ordination (DCA) for 10 forest types. Each vector represents a forest type and each number (i.e. 30, 40, 50, 60) represents its height class ( 60 stands for the $\geq 12 \mathrm{~m}$ class 30 the $\leq 1 \mathrm{~m}$ class or regeneration). Forest types are identified by dominant species acronyms: BFI $=$ balsam fir $; \mathrm{BSP}=$ black spruce $; \mathrm{DIE}=$ Diervilla lonicera $; \mathrm{DRS}=$ Dryopteris spinulosa $; \mathrm{JPI}=$ jack pine; PLS $=$ Pleurozium schreberi $; \mathrm{SAL}=$ speckled alder; SPS $=$ Sphagnum sp.; TAS $=$ trembling aspen; WBI $=$ white birch.

Forest types BSP-SPS and BSP-SAL-SPS are grouped in the black Spruce/Sphagnum - RE3 successional series; BSP-JPI, TAS-BSP, BSP-PLS are grouped in the black spruce/feathermoss - RE2 successional series; BSP-WBI, BFI-BSP, BSP-BFI, WBI-DIE, WBI-DRS are grouped in the black spruce balsam RE-5 successional series.

These results are part of the forest ecological classification of 12b-lac Chibougamau ecological region (Bergeron 1992b).

The various ecological classification products developed through this process are combined in the integrated forest inventory map ("carte éco-forestière") at a scale of 1:20,000 (Figure 7). This map represents the final product of the FEC program. The production of these maps involves the following steps: photo-interpretation of the stand; interpretation of geomorphological features (surface deposits, moisture regime, slope); and interpretation of successional series. Stand and ecological photo-interpretation is conducted by means of 1:15,000 infrared aerial photographs. The mapped polygons from the aerial photographs are then transferred onto a 1:20,000 base map. To verify the accuracy of integrated forest inventory maps, a ground-truth procedure is carried out. This map consists of homogeneous mapping units which are annotated with information on several variables : surface deposit type and thickness, soil drainage, slope class, successional series and forest stratification (Figure 7). Recently the SIF has begun to investigate applications of the ecological classification. Interpretive maps have been developed at a scale of 1:20,000 for themes such as reforestation, spruce budworm vulnerability and deer habitat management.

\section{Conclusion}

The most important parameters characterizing the forest types encountered in an ecological region are summarized in a technical report that provides an ecological overview of that ecological region (e.g. La Végétation forestière de la région écologique 5a-Basses et Moyennes Appalaches: Saucier 1989). In this document, forest types are described by fact sheets highlighting the FEC products presented above. The first parameters described are the forest type physiognomy and species composition, with an emphasis on dominant and indicator species. These are identified in the forest type identification key. All the environmental variables are described on the fact sheets for each forest type. Histograms and ordination diagrams are used for this purpose. The successional status of each forest type is discussed, 


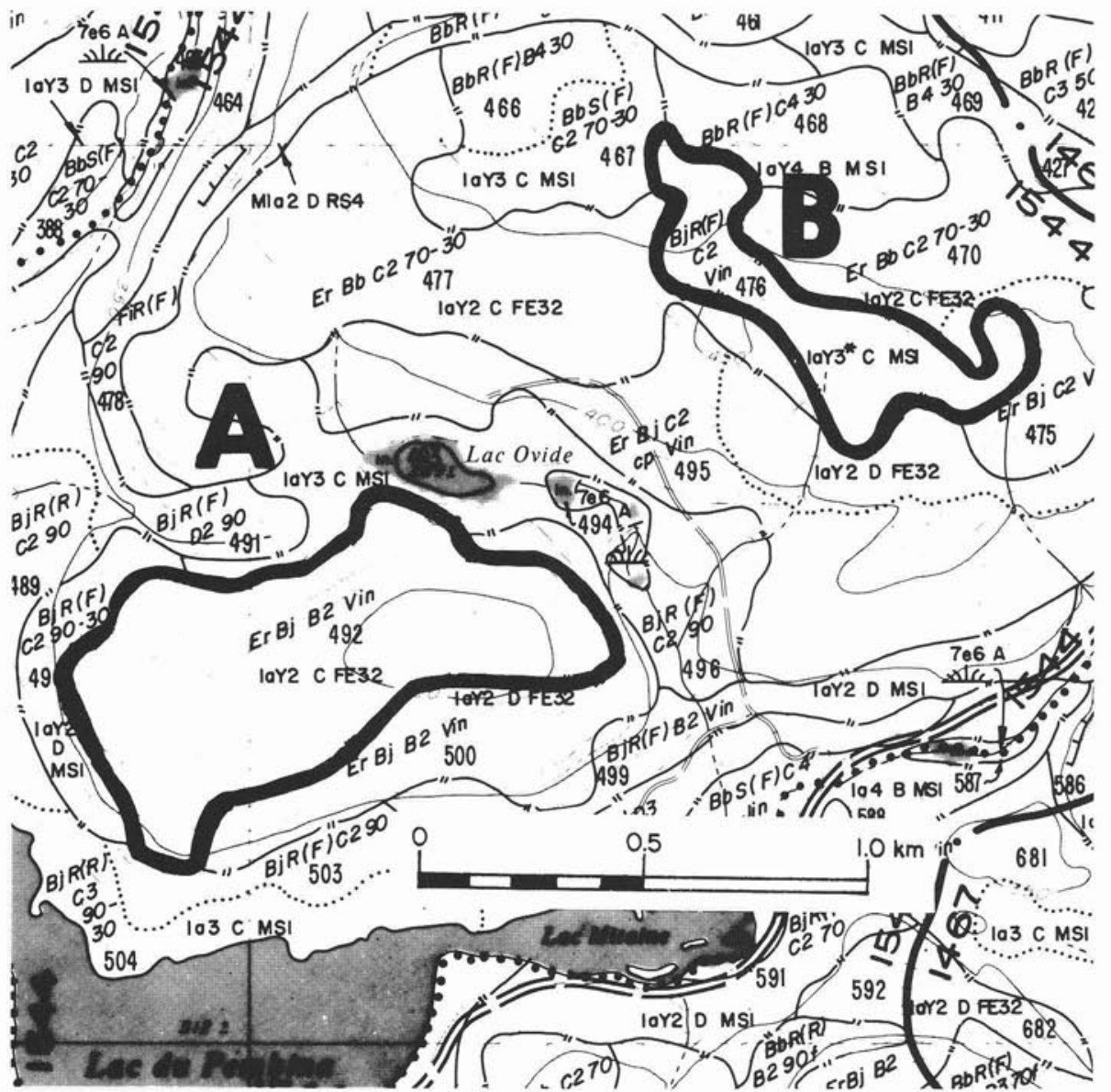

Figure 7. Integrated forest inventory map at a scale of 1:20,000. This excerpt is taken from the $31 \mathrm{I} / 11 \mathrm{~N}$.E. map sheet. Mapping units $\longrightarrow 11 \longrightarrow$ delineate homogeneous forest stands and corresponding site characteristics. Each mapping unit or polygon is characterized by an ecological type designation and a forest stratification. Two mapping units (A and B) highlighted in the map are described.

\begin{tabular}{|c|c|c|}
\hline & A & B \\
\hline Ecological type & 1 AY2 C FE 32 & $1 \mathrm{AY} 3^{*} \mathrm{C}$ MS1 \\
\hline $\begin{aligned} \text { Deposit: } & \text { - type } \\
& =\text { tickness } \\
& =\text { moisture regime }\end{aligned}$ & $\begin{array}{l}\text { Glocial till (1 AY) } \\
50-99 \mathrm{~cm} \text { (1 AY) } \\
2\end{array}$ & $\begin{array}{l}\text { Glacial type (1AY) } \\
50-99 \mathrm{~cm} \text { (1AY) } \\
3 \text { with seepage (*) }\end{array}$ \\
\hline Slope & $8-15 \%$ (c) & $8-15 \%(C)$ \\
\hline Successional series & $\begin{array}{c}\text { Sugor mople - yellow birch } \\
\text { FE } 32\end{array}$ & $\begin{array}{l}\text { Bolsom fir- yellow birch } \\
\text { MS } 1\end{array}$ \\
\hline Forest stratification & ErBj B2 Vin & $\operatorname{BjR}(F)$ C2 Vin \\
\hline Species group ${ }^{1}$ & $\begin{array}{l}\text { ErBj : } \\
\text { Sugar maple : } 33-66 \% \\
\text { Yellow birch: } 33-50 \%\end{array}$ & $\begin{array}{l}\text { BjR (F): } \\
\text { Yellow birch: } 51-75 \% \\
\text { Conifer : } 26-50 \% \\
\text { Balsom fir and wite spruce }\end{array}$ \\
\hline Density / height & $60-80 \% / 17-22 \mathrm{~m}(\mathrm{B2})$ & $40-60 \% / 17 m-22 m(C 2)$ \\
\hline Age closs & Old uneven (Vin) & Old uneven (Vin ) \\
\hline
\end{tabular}

1 Bosed on basol oreo 


\section{A-RS42-5.3 EPR/PLS VAM}

Pessière à épinette rouge / mousses, Vaccinium

\begin{tabular}{lll}
\hline Région écologique: & $4 \mathrm{~A}$ & Collines de Mégantic, lac Etchemin \\
Série évolutive: & RS42 & Sapinière à épinette rouge typique \\
Stade évolutif: & 5.3 & État soutenu \\
Nombre de relevés: & 35 &
\end{tabular}
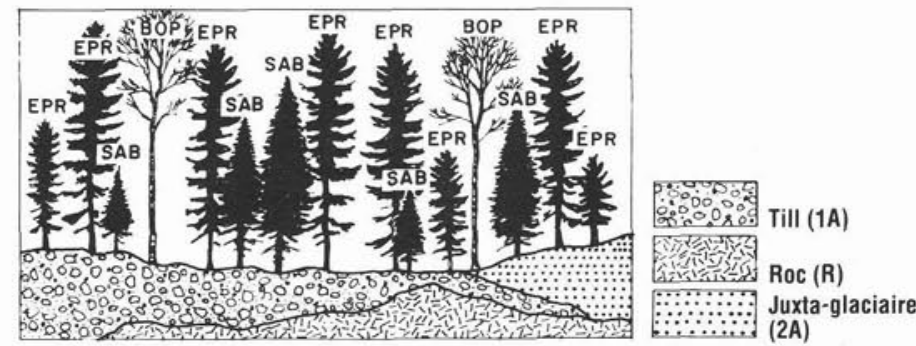

\section{Composition en espèces}

\begin{abstract}
Strate arborescente (70 - 95\%)
Dominantes: Picea rubens ${ }^{8}$

Compagnes: Abies balsamea ${ }^{1}$

Sporadiques: Betula papyrifera ${ }^{+}$

Strate arbustive

Commerciale (30\%)

Dominantes: Abies balsamea ${ }^{3}$

Compagnes: Picea rubens ${ }^{1}$

Sporadiques: Betula papyrifera ${ }^{+}$

Acer rubrum ${ }^{+}$
\end{abstract}

Strate herbacée (25\%)

Dominantes: Cornus canadensis ${ }^{1}$

Compagnes: Pteridium aquilinum ${ }^{1}$, Clintonia borealis ${ }^{1}$, Chiogenes hispidula $^{1}$,

Sporadiques: Trillium undulatum ${ }^{1}$, Epigea repens ${ }^{1}$

Maianthemum canadensis ${ }^{1}$, Gaultheria procumbens ${ }^{+}$,

Pyrola secunda ${ }^{+}$

Strate muscinale (40 - 75\%)

Dominantes: Pleurozium schreberi ${ }^{4}$, Dicranum $\mathrm{sp}^{4}$

Compagnes: Ptilium crista-castrensis ${ }^{1}$, Bazzania trilobata ${ }^{1}$,

Sporadiques: Sphagnum girgensohnii ${ }^{1}$

Hylocomium splendens ${ }^{+}$, Polytrichum sp. ${ }^{+}$, Cladina rangiferina ${ }^{+}$

Figure 8. Fact sheet describing the red spruce, moss, Vaccinium forest type. This example is part of the FEC field guide prototype developed for the Appalachian region, ecological regions 3e, 4a, $5 \mathrm{~b}$ (Grondin et al. 1991). The forest type number contains the following information: ecological region, $4 \mathrm{~A}$; sucessional series and successional stage, RS42-5.3; overstory dominant species and indicator species, EPR/PLS-VAM

The following forest type attributes are illustrated:

- stand structure (diagram);

- species composition: tree layer, shrub layer, herbaceous and moss layer (strate arborescente, arbustive, herbacée, muscinale);

- soil characteristics, including surface deposit, drainage, texture, stoniness, roughness (dépôt, drainage, texture, pierrosité, rugosité);

- topographical features, including slope position, exposure, altitude and slope class (situation and versant, exposition, altitude, pente);

- soil type (type de sol);

- humus type (type d'humus);

- distribution (distribution);

- successional status (dynamisme);

- species group (strates forestières); and

- remark (remarque).

Acronyms and codes used in this figure are described in Robert and Saucier (1988). 
Milieu physique

\begin{tabular}{|c|c|c|c|c|c|c|c|c|c|}
\hline \multirow{2}{*}{ Dépôt tiques } & \multicolumn{6}{|c|}{ Drainage } & & \multirow{2}{*}{$\begin{array}{c}\text { Pierrosité } \\
(\%) \\
\end{array}$} & \multirow[t]{2}{*}{ Rugosité } \\
\hline & 1 & 2 & 3 & 4 & 5 & & & & \\
\hline $\mathbf{R}$ & $\oplus$ & & & & & & 一 & \multirow{2}{*}{$50-60$} & \multirow{2}{*}{$3-4$} \\
\hline M1A & $\oplus$ & & & & & & \multirow{5}{*}{ B:LS/C:LS } & & \\
\hline $1 \mathrm{AM}$ & & $\bigoplus$ & & & & & & \multirow{3}{*}{$30-60$} & \multirow{3}{*}{3} \\
\hline 1AY & & & $\theta$ & & & & & & \\
\hline $1 \mathrm{~A}$ & & & & & $\theta$ & & & & \\
\hline 1AD & & & & & $\bigoplus$ & & & $>70$ & $3-4$ \\
\hline $2 A$ & & & $\oplus$ & $\oplus$ & & & B:SUC:S & 30 & 2 \\
\hline 3AN & & & & & P & & B:LS/C:LS & 10 & 1 \\
\hline
\end{tabular}

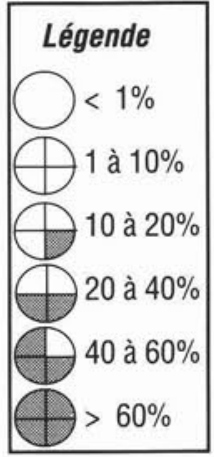

Topographie

\begin{tabular}{|l|l|l|l|l|}
\hline Sersant & $\begin{array}{l}\text { Sommet } \\
\text { haut de } \\
\text { pente }\end{array}$ & $\begin{array}{l}\text { Bas de } \\
\text { pente }\end{array}$ & Mi-pente & $\begin{array}{l}\text { Terrain } \\
\text { plat/ } \\
\text { replat }\end{array}$ \\
\hline Haut & & & & \\
\hline Moyen & & & & \\
\hline Bas & & $(1)$ & & \\
\hline
\end{tabular}

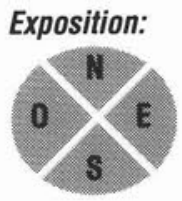

Altitude:

260 à $410 \mathrm{~m}$

Pente:

$B^{5}, A^{3}, C^{2}$

\section{Types de sol: $\quad \mathrm{PHFGL}^{7}, \mathrm{PHFO}^{1}, \mathrm{GO}^{1}$ \\ Types d'humus: $\quad \operatorname{Mor}^{9}(10 \pm 4 \mathrm{~cm})$, tourbe ${ }^{1}(20 \pm 5 \mathrm{~cm})$}

Distribution: $\quad$ Fréquent dans l'ensemble physiographique $U$ - Coteaux des Basses-Appalaches

Dynamisme: $\quad$ Type forestier d'état soutenu qui peut se régénérer par le feu. Suite aux coupes ou en l'absence de perturbation, il peut évoluer vers la sapinière à épinette rouge, mousses et Vaccinium. $\mathrm{Ce}$ type forestier provient de feu ou de coupe. II peut également être issu d'une dégradation de la sapinière à épinette rouge, mousses et Vaccinium, à la suite d'une épidémie de tordeuse des bourgeons de l'épinette.

Strates forestières: $\mathrm{E}$

Remarque: Dans la strate arborescente, l'épinette rouge est parfois remplacée par l'épinette noire.

with an emphasis on stand origin, related disturbances and successional pattern. The forest type distribution within each ecological region is also examined.

Toposequences, initially developed to aid ecological photointerpretation for mapping purposes, are now being used by field foresters to help them identify the forest stands that can be expected to develop after harvesting given certain site conditions. Toposequences are also useful for harvesting, stand improvement and reforestation planning purposes. The integrated forest inventory and interpretive maps based on the products described above constitute a multipurpose silvicultural tool. Identification of ecological variables on a 1:20,000 scale provides a planning tool that helps foresters to select better and more appropriate silvicultural treatments on the basis of a comprehensive knowledge of the forest environment. The use of these integrated forest inventory maps, ecological district $(1: 250,000)$ and surface deposit $(1: 50,000)$ maps, in combination with the toposequences, helps forest managers solve problems involving road network establishment, identification of sensitive sites, stand vulnerability to spruce budworm, etc.

Quebec's FEC system differs in a number of ways from other previously developed classification approaches. It integrates all the ecological variables to create a comprehensive FEC program. Because of the vast size of Quebec's forests $\left(652000 \mathrm{~km}^{2}\right)$, the SIF has also developed a high level of technical expertise in ecological survey work. More than 60 technicians and professionals from the Service as well 
as private-sector consulting firms participate in ecological surveys each year. Detailed methodological guides and analytical procedures which are applicable to any other forested land area have been developed to treat and analyze large amounts of detailed and often complex data (Saucier et al., in preparation).

Current initiatives involve the incorporation of forest productivity data into the FEC to determine the productivity of ecological types. The information contained in the FEC of specific ecological regions constitutes a basis for the development and production of FEC and management interpretation field guides. Prototypes of both types of field guide have been developed for the Appalachian region (Grondin et al. 1991). Two pages from the FEC field guide prototype illustrating the forest type fact sheets are reproduced in Figure 8. On a broader level, the MFO is currently developing geographic information systems (GIS) which will link together forest inventory, forest ecological classification, wildlife, landscape and hydrographic components into a unified information system. These activities are a part of Québec's integrated resource management project. This program, involving several ministries concerned with resource management, incorporates the use of the FEC, which provides data and interpretations on forest ecosystems (Anonymous 1991). The wide range of ecological classification products described in this paper makes it possible to meet the many needs related to forest ecosystem management in Québec.

\section{References}

Anonymous. 1991. La gestion intégrée des ressources - résumé du projet de développement. Gouv. Québec, Quebec. 20 p.

Bailey, R.G. 1976. Ecoregions of the United States. U.S. Dept. Agric. (USDA) For. Serv., Intermountain Reg., Ogden, Utah. Scale 1:7 500000 .

Bélanger, L.Y., Bergeron and C. Camiré. 1992. Ecological land survey in Québec. For. Chron. 68 (1) 42-52.

Bélanger, L., J.-P. Ducruc and M. Pineau. 1983. Proposition d'une méthodologie d'inventaire écologique adaptée au territoire forestier périurbain. Naturaliste canadien 110: 459-476.

Bergeron, J.-F., 1992a. La Végétation forestière de l'Ile Anticosti, régions écologiques $8 \mathrm{~m}$ et $10 \mathrm{a}$, classification de la végétation et relations végétation-milieu physique. Minist. For. Qué., Serv. inventaires for. (in prep.)

Bergeron, J.-F. 1992b. La végétation forestière du secteur sudouest de la région écologique 12b-Lac Chibougamau, Minist. For. Qué., Serv. inventaires for. (in prep.)

Bergeron, Y., A. Bouchard, P. Gangloff and C. Camiré. 1983. La classification écologique des milieux forestiers de la partie ouest des cantons d'Hébécourt et de Roquemaure en Abitibi, Québec. Étud. écol., No. 9, Univ. Laval, Québec. 169 p.

Bouchard A., Y. Bergeron, C. Camiré, P. Gangloff and M. Gariépy. 1985. Proposition d'une méthodologie d'inventaire et de cartographie écologique, le cas de la MRC du HautSaint-Laurent. Cah. géogr. Qué. 36 : 291-305.

Christian, C.S. and G.A. Stewart. 1968. Methodology of integrated surveys. Pages 233-280 in Proceeding of Aerial Surveys and Integrated Studies Conference, UNESCO, Toulouse.

Daubenmire, R.F. 1952. Forest vegetation of northern Idaho and adjacent Washington, and its bearing on concepts of vegetation classification, Ecol. Monogr. 22: 301-330.

Ducruc, J.-P. 1986. Information écologique et aménagement régional du territoire : pour un véritable cadre écologique de référence. Contrib. Div. cartogr. écol., No. 27. Dir. patrimoine écol., Minist. Environ. Qué., Québec. 192 p.
Gérardin, V. and J.-P. Ducruc. 1990. The ecological reference framework for Québec: A useful tool for forest sites evaluation. Vegetatio 87: 19-27.

Goff, F.G. and P.H., Zedler. 1972. Derivation of species succession vectors. Amer. Midland Naturalist 87: 397-412.

Grondin, P., J.-P. Saucier, J.-F. Bergeron and A. Robitaille. 1991. Prototypes de guide de reconnaissance du milieu physique et des types forestiers et de guide sylvicole. Région des Appalaches, Minist. For. Qué. 57 p.

Hill, M.O. 1979a. DECORANA - A Fortran program for detrended correspondence analysis (DCA) and reciprocal averaging. Cornell Univ., Ithaca, New York. 52 p.

Hill, M.O. 1979b. TWINSPAN - A Fortran program for arranging multivariate data in an ordered two-way table by classification of individuals and attributes. Cornell Univ., Ithaca, New York. 90 p.

Hill, G.A. 1959. A ready reference to the description of the land of Ontario and its productivity. Ont. Dept. Lands For. Div. Res. 142 p.

Jones, R.K., G. Pierpoint, G.M. Wickware, J.K. Jeglum, R.W. Arnup and J.M. Bowles 1983. Field guide to forest ecosystem classification for the Clay Belt, Site Region 3E. Ont. Minist. Nat. Resour., Toronto, Ontario. 123 p.

Jurdant, M., J.-C., Dionne, V., Gérardin, and J. Beaubien. 1969. Inventaire biophysique de la région Mistassini, Roberval, Hébertville (Québec). Projet pilote du comité national des terrains forestiers, rapport d'information QX-12, L'inventaire du Capital-Nature. Lab. rech. for., Dir. gén. for., Minist. Pêches For. 162 p.

Jurdant, M., J.L. Bélair, V. Gérardin, and J.-P. Ducruc. 1977. L'inventaire du Capital-Nature. Serv. Étud. Écol. Rég., Dir. rég. terres, Pêches Environ. Can., Québec. 202 p.

Lacate, D.S. 1969. Guidelines for biophysical classification. Can. Dept. For., Can. For. Serv. Publ. $n^{\circ} 4.61$ p.

Ozenda, P. 1964. Biogéographie végétale. Douin, Paris. 374 pp.

Rey, P. 1960. Essai de phytocinetique biogéographique. C.N.R.S., Paris. 399 pp.

Robert, D. and J.-P. Saucier. 1988. Normes de prise de données et de vérification. Minist. Énergie Ressour., Serv. inventaire for., Québec. 180 p.

Robitaille, A. 1989. Cartographie des districts écologiques : normes et techniques. Minist. Énergie Ressour., Serv. inventaires for., Div. écol. Québec. 109 p.

Robitaille, A., and J.-P. Saucier. 1989. Caractérisation du relief des districts écologiques. Minist. Énergie Ressour., Serv. inventaires for., Div. écol. Québec. 15 p.

Saucier, J.-P. 1989. La végétation forestière de la région écologique 5a-Basses et Moyennes Appalaches. Minist. Énergie Ressour., Serv. inventaire for., Div. écol. Québec. 196 p.

Saucier, J.-P., J.-F. Bergeron and H. D'Avignon, 1992. Méthodes de classification écologique de la végétation forestière. Minist. for., Serv. inventaires for. Québec. (in prep.).

Sims, R.A., W.D. Towill, K.A. Baldwin and G.M. Wickvare. 1989. Field guide to the forest ecosystem classification for northwestern Ontario. Ont. Minist. Nat. Resour., Toronto, Ontario. 191 p.

ter Braak, C.J.F. 1987. CANOCO - a Fortran program for canonical community ordination by partial detrended canonical correspondence analysis. ITI-TNO, Wageningen. 95 p.

Thibault, M. 1985. Les régions écologiques du Québec méridional (deuxième approximation). Minist. Énergie Ressour., Serv. rech. Québec. Scale 1:250 000.

Thie, J. and G. Ironside. 1977. Ecological Land Classification in Canada. Ecol. Land Classif. Ser., No. 1, Lands Dir., Environ. Can., Ottawa. 269 p.

Wertz, W.A. and J.F. Arnold. 1972. Land Systems inventory. USDA For. Serv., Intermountain Reg., Ogden, Utah. 12 p. 